\title{
Skull Base Neoplasm
}

National Cancer Institute

\section{Source}

National Cancer Institute. Skull Base Neoplasm. NCI Thesaurus. Code C4676.

A benign or malignant neoplasm that affects the skull base. 